\title{
Financial Distress and Corporate Governance around Lehman Brothers Bankruptcy
}

\author{
Xavier Brédart ${ }^{1}$ \\ ${ }^{1}$ Warocqué School of Business and Economics, University of Mons, Mons, Belgium \\ Correspondence: Xavier Brédart, Warocqué School of Business and Economics, University of Mons, Place \\ Warocqué, 17, 7000, Mons, Belgium. Tel: 32-6537-3213. E-mail: xavier.bredart@umons.ac.be
}

Received: February 11, 2014

Accepted: March 13, 2014

Online Published: April 24, 2014

doi: $10.5539 /$ ibr.v7n5p1

URL: http://dx.doi.org/10.5539/ibr.v7n5p1

\begin{abstract}
United States faced a growing number of corporate bankruptcies during the subprime crisis. This article is intended to determine the effectiveness of some governance mechanisms on the financial distress probability of companies over the period 2007-2009. This period is divided into two parts; we take the date of filing for chapter 11 of the company Lehman Brothers (15 December, 2008) as the cutting point between the mortgage and the financial phases of the crisis. Aiming to highlight the influence of corporate governance mechanisms on financial distress probability, we then use, for each sub period, logit models on paired samples of firms which half opted for legal protection due to financial and commercial difficulties. Our results indicate that, during the first sub period, combining the functions of CEO and chairman of the board of directors is beneficial to the survival of the firm, whereas, during the second sub period, capital ownership by the CEO appears to be an incentive to keep the firm on float. This paper seeks to add to the corporate governance literature by considering how certain corporate governance mechanisms impacted the perennity of companies during the subprime crisis.
\end{abstract}

Keywords: bankruptcy, Lehman Brothers, corporate governance

\section{Introduction}

During the recent crisis, many firms fell into distress and filed for bankruptcy (Li \& Zhong, 2013). Many forces led to the largest economic crisis since the Great Depression of the 1930's and corporate governance is one of the contributing factors. Moreover, corporate governance mechanisms failed to cope with the crisis as it unfolded (Conyon, Judge, \& Useem, 2011). Financial distress detection represents a major issue in the finance and accounting literature due to its impact for many actors (e.g., banks and investors). The huge majority of bankruptcy detection models consider accounting and financial data only as explanatory factors (Beaver, 1967; Altman, 1968; Refait, 2004). Relatively few studies (Chaganti, 1985; Hambrick \& D'Aveni, 1992; Gales \& Kesner, 1994; Daily \& Dalton, 1994; Daily, 1996; Donoher, 2004; Lajili \& Zéghal, 2010; Platt \& Platt, 2012) analyzed the relation between the occurrence of bankruptcy filing and the governance structure of firms. We suggest this recent context of crisis provides a unique research setting to study corporate governance and its impact on financial distress. The subprime crisis may be divided into different phases. We focus on the mortgage and the financial phases of the crisis. We take the date of filing for chapter 11 of the company Lehman Brothers as the cutting point between the mortgage and the financial phases of the crisis.

In this paper, we examine the impact of characteristics linked to corporate governance on the probability of financial distress of American quoted companies in the context of the subprimes crisis. We test some corporate governance mechanisms during the mortgage and the financial phases of the crisis in order to determine if the same factors have an impact on the decision to file for a bankruptcy protection law. To this end, we use a unique dataset of firms that filed for chapter 7 (liquidation procedure) or chapter 11 (reorganization procedure) of the American bankruptcy code and compare, through logit models, some characteristics to a match pair sample of firms that did not resort to bankruptcy protection. The results of our study highlight differences between the two sub periods; these concern the impact of ownership and CEO duality on financial distress probability.

In the next section, we develop the theoretical framework underpinning our study, including a discussion of the rationale for using the subprime crisis context and the inclusion of corporate governance variables into the models. Following the development of testable hypotheses, we discuss the data, the methodology employed and the results from our analysis. We conclude with a discussion of the findings including theoretical and managerial 
implications.

\section{Subprime Crisis and Corporate Governance}

If, since 1930, the United States has already overcome several financial crises, the current one seems to be quite different. Far from being limited to one segment of the market, this financial crisis spread from one part of the economy to the others, holding up the functioning of the worldwide financial market. Although several causes can be pointed out (including poor corporate governance), this first significant worldwide crisis since 1930 is, mainly to be imputed to cheap credit in the United States, which led to a speculative bubble and later to its burst - which experts agree to date from mid-2007 (Attali, 2008). It is indeed at that time that secured real estate assets began to spark doubts off when American Home Mortgage, one of the most important mortgage companies in the USA, got involved in a bankruptcy procedure. On 15 September 2008, the bank Lehman Brothers filed for chapter 11. The crisis entered into a new phase: the financial one. The difficulties of the financial sector generated a credit crunch that consequently affected the whole economic system and many firms had to file for bankruptcy protection. As the subprimes crisis started in the United States, firms quoted on American markets have logically been the first ones to be impacted. For this reason, we decided to conduct our analysis on this area. As per many experts, corporate governance has been pointed out as one of the causes of this turmoil. In this article, we test the impact of some corporate governance mechanisms on the durability of US firms during the first two phases of the subprimes crisis. These mechanisms are the size and the independence of the board of directors, the percentage of capital held by the CEO and the potential duality of the roles of CEO and chairman.

Size of the board of directors. The main argument in favor of a larger board of directors is that the increase in the number of members raises their disciplinary control over the CEO. The positive relation between the size of the board and the firm performance thanks to the board has been empirically checked by Kiel and Nicholson (2003). The main argument against a wider board of directors is that it implies increased communication and coordination costs for administrators (Jensen, 1993). From an empirical point of view, Yermack (1996) and Eisenberg, Sundgren and Wells (1998) report an inverse association between board size and firm performance. Cheng (2008) associates larger boards with low variability in the results of the firm. This implies that a larger board requires more compromises to reach a consensus, and consequently that decisions are less extreme. From an empirical point of view, studies by Chaganti et al. (1985) and Hambrick and D'Aveni (1992) and Gales and Kezner (1994), carried out on paired samples, report that boards of companies having filed for a bankruptcy protection chapter are characterized by a smaller number of directors.

We formulate the first hypotheses as follow:

H1a: During the mortgage phase of the crisis, firms with a large number of directors on the board were less likely to experience financial distress and file for bankruptcy protection.

H1a: During the financial phase of the crisis, firms with a large number of directors on the board were less likely to experience financial distress and file for bankruptcy protection.

Independence of the board. As per Weisbach (1988), independent directors would be fairer than their dependent counterparts. Independent directors are indeed less subject to have inherent contracts with the CEO. From an empirical point of view, studies by Choi, Park and Yoo (2005) report a positive relation between the presence of independent directors and the performance of the firm, which is especially strong when companies must cope with difficulties. On the other side, Kiel and Nicholson (2003) report a positive correlation between the proportion of internal directors and evolution of stock prices. Last, following a review of 85 empirical studies, Daily, Dalton, Ellestrand and Johnson (1998) reach the conclusion that no relation may be established between board composition and performance. Nevertheless, most of the governance codes recommend increasing the independence of the board. Therefore, we will assert our second hypothesis as follows.

H2a: During the mortgage phase of the crisis, firms with a high proportion of independent directors on the board are less likely to experience financial distress and file for bankruptcy protection.

H2b: During the financial phase of the crisis, firms with a high proportion of independent directors on the board are less likely to experience financial distress and file for bankruptcy protection.

Percentage of capital held by the CEO. Adams et al. (2011) argue that the managerial incentive alignment predicts that as insider ownership increases, managers' interests become more closely aligned with shareholders' interests. Equity ownership by the CEO may motivate him to create value for shareholders. Indeed, as part-owner of the company, the gap between his own utility function and that of the shareholders is reduced (Beatty \& Zajac, 1994; Rediker \& Seth, 1995). In line with this hypothesis of convergence of interests, Jensen 
and Meckling (1976) observed a positive relationship between CEO ownership and the value of the firm and argue that managers' equity ownership reduces agency costs. Also, the empirical study of Bhagat and Bolton (2008) reports a positive relationship between the holding of equity by the management and future operational firm performance. In the context of bankruptcy prediction, we argue that CEO ownership is an important aspect of his motivation to manage the company in a perennial way because the firm represents a part of his personal wealth. Thus, we posit that the more company shares the CEO holds, the more he will be motivated to manage it in a perennial way. More formally stated.

H3a: During the mortgage phase of the crisis, firms which CEO holds a higher percentage of the capital are less likely to experience financial distress and file for bankruptcy protection.

H3b: During the financial phase of the crisis, firms which CEO holds a higher percentage of the capital are less likely to experience financial distress and file for bankruptcy protection.

Duality as CEO and chairman of the board of directors. As per Adams et al. (2011), CEO duality tends to affect firm performance. Holding the role of both CEO and chairman of the board of directors makes his evaluation more difficult, increases agency costs and entrenchment risks (Fama \& Jensen, 1983; Lipton \& Lorsch, 1992; Jensen, 1993) and can potentially impact board decision making (Cutting \& Kouzmin, 2002). This is because the board, being in principle the organ in charge of controlling the actions of the managers, is headed by the very object of this overseeing. Furthermore, Westphal and Zajac (1995) suggest that when the CEO performs the dual role of chairperson on the board, he may be more likely to select board members who will not challenge him/her. Empirically, many studies suggest that separating these functions results in better performances by firms (Rechner \& Dalton, 1991; Pi \& Timme, 1993; Boyd, 1995; Bhagat \& Bolton, 2008; Balsam \& Upadhyay, 2009). On the other hand, as per Depret et al. (2005), the simultaneous holding of these functions could provide companies with an increased flexibility that may be an advantage in some circumstances, as in a crisis period, for instance. Nevertheless, Organization for Economic Co-operation and Development (2004) recommends separating the two functions. For this reason, we formulate the last hypotheses as follow:

H4a: During the mortgage phase of the crisis, firms characterized by CEO duality are more likely to experience financial distress and file for bankruptcy protection.

H4b: During the financial phase of the crisis, firms characterized by CEO duality are more likely to experience financial distress and file for bankruptcy protection.

\section{Methodology}

\subsection{Sample and Data}

The sample used in this study consists of 312 firms originally quoted on the Amex, the Nasdaq and the NYSE from mid-2007 to 2009. Half of the total sample filed for chapter 7 or 11 of the United States Bankruptcy Code and transferred their quotation on an OTC market during this timeframe. The other half of the sample consists of firms without any filing for bankruptcy protection law during the timeframe. We matched firm size (via total assets) and industry (via SIC code). Governance data was then collected by hand from SEC DEF 14A proxy statements preceding the filing for bankruptcy while financial data is outsourced from Bloomberg database. We used software Stata 11.0 to analyse the data. We finally separate our sample into two parts depending on the filing date of firms for chapter 7 or 11: before or after the filing date for chapter 11 of Lehman Brothers (15 September, 2008).

\subsection{Measures}

Dependent Variable. Our dependent variable is Financial distress. Financial distress is a dichotomous variable which takes a value of 1 if the firm filed for chapter 7 or 11 of the United States Bankruptcy Code and 0 otherwise.

Independent Variables. Our key explanatory variables are Board size, board independence, CEO ownership and $C E O$ duality. Board size is measured as the number of directors on the board on the latest accounting fiscal year before the filing for bankruptcy procedure. Board independence represents the percentage of independent directors on the board on the latest accounting fiscal year before the filing for bankruptcy procedure. We define CEO ownership as the percentage of shares held by the CEO divided by the firm's total number of outstanding shares on the latest accounting fiscal year before the filing for bankruptcy procedure. As Boyd (1995), we create a dummy variable for $C E O /$ Chairman duality which takes a value of 0 for if $\mathrm{CEO}$ and chair roles are separated on the last accounting fiscal year before the filing for bankruptcy procedure, and 1 otherwise.

Control Variables. In order to take account of firm-related effects, we also incorporated in our model two 
accounting ratios that were calculated for the latest accounting fiscal year before filing for bankruptcy protection: the Return on Equity (ROE) and the structural solvency ratio (Note 1). The idea that a better performance and solvency positively influence company perennity is reinforced by Altman's empirical study (1968).

\subsection{Methodology}

The dependent variable, financial distress, is dichotomous. Therefore, we use a binary logit regression model as it is in many studies of that kind (Ohlson, 1980; Platt \& Platt, 1991; Premachandra, Bhabra, \& Sueyoshi, 2009). A logit model represents the relationship between a binary dependent variable that takes value 1 (financial distress) or value 0 (no financial distress), and $\mathrm{k}$ explanatory variables $\mathrm{x}_{1}, \mathrm{x}_{2} \ldots \mathrm{x}_{\mathrm{k}}$. As our dependent variable is dichotomous, it follows Bernoulli distribution such that $\mathrm{Pi}=\mathrm{P}(\mathrm{yi}=1)$ is the probability of financial distress and 1 - $\mathrm{Pi}$ is the probability of non-financial distress. The estimated model requires the endogenous variable to be a linear combination of exogenous variables:

$$
y i^{*}=\beta X i+\varepsilon i
$$

where $\varepsilon$ is the error term and $\beta$ the vector of coefficients

$\mathrm{yi}=1$ if $\mathrm{yi}^{*}>0$

$\mathrm{yi}=0$ if $\mathrm{yi}^{*} \leq 0$

The probability of non-financial distress of firm $i$ is:

$$
P(y i=0)=P\left(y i^{*} \leq 0\right)=P(\beta X i+\varepsilon i \leq 0)=P(\varepsilon i \leq-\beta X i)=F(-\beta X i)=1-F(\beta X i)=1-P i
$$

And, the probability of financial distress of firm i is represented by:

$$
P(y i=1)=P\left(y i^{*}>0\right)=P(\beta X i+\varepsilon i>0)=P(\varepsilon i>-\beta X i)=1-P(\varepsilon i \leq-\beta X i)=F(\beta X i)=P i
$$

It is possible to calculate the probability of non-financial distress of firm I as follows:

$$
P(y i=0)=F(-\beta X i)=(1+e \beta X i)-1=1-P i
$$

Similarly, the probability of financial distress of firm $\mathrm{i}$ is:

$$
P(y i=1)=F(X i \beta)=(1+e-\beta X i)-1=P i
$$

The $\beta$ coefficients are estimated with the method of maximum likelihood.

\section{Results}

\begin{tabular}{|c|c|c|c|c|c|c|c|c|c|c|c|c|c|}
\hline & & \multicolumn{6}{|c|}{ Before 15 september 2008} & \multicolumn{6}{|c|}{ After 15 september 2008} \\
\hline & & 1 & 2 & 3 & 4 & 5 & 6 & 1 & 2 & 3 & 4 & 5 & 6 \\
\hline 1 & ROE & 1 & & & & & & 1 & & & & & \\
\hline 2 & Solvency & -0.22 & 1 & & & & & -0.05 & 1 & & & & \\
\hline 3 & Board size & -0.04 & 0.04 & 1 & & & & 0.08 & -0.02 & 1 & & & \\
\hline 4 & Board independence & 0.00 & 0.07 & -0.03 & 1 & & & -0.03 & -0.04 & 0.16 & 1 & & \\
\hline 5 & CEO ownership & 0.04 & -0.05 & -0.10 & -0.09 & 1 & & -0.05 & 0.04 & -0.03 & -0.05 & 1 & \\
\hline 6 & CEO duality & -0.02 & -0.04 & -0.03 & 0.00 & 0.19 & 1 & -0.06 & 0.08 & 0.10 & 0.03 & 0.24 & 1 \\
\hline
\end{tabular}

\subsection{Correlations and Descriptive Statistics}

Table 1 reports correlations between explanatory variables for the two sub-periods. As all coefficients are below 0.3 , we do not have any multicolinearity problem.

Table 1. Correlation matrixes

Table 2 reports descriptive statistics (mean and standard deviation) for variables included in the logistic model for the two sub-periods of interest. 
Table 2. Mean and standard deviation of explanatory variables before and after Lehman Brothers filing date on 15 September 2008

\begin{tabular}{lllllll}
\hline & \multicolumn{2}{l}{ Before 15 September 2008 } & & \multicolumn{2}{l}{ After 15 September 2008 } \\
\cline { 2 - 7 } & Total sample & Financial distress & Healthy & Total sample & Financial distress & Healthy \\
\hline ROE & $0.33(1.9)$ & $0.65(2.66)$ & $0.01(0.25)$ & $-0.58(3.49)$ & $-0.82(4.65)$ & $-0.35(1.65)$ \\
Solvency & $0.21(0.64)$ & $-0.03(0.79)$ & $0.46(0.29)$ & $0.12(1.32)$ & $-0.16(1.81)$ & $0.4(0.3)$ \\
Board size & $7.93(2.4)$ & $7.5(1.7)$ & $8.36(2.9)$ & $8.32(2.48)$ & $8.22(2.31)$ & $8.41(2.66)$ \\
Board independence & $0.73(0.14)$ & $0.72(0.15)$ & $0.73(0.13)$ & $0.75(0.15)$ & $0.74(0.17)$ & $0.76(0.13)$ \\
CEO ownership & $0.08(0.09)$ & $0.08(0.05)$ & $0.08(0.11)$ & $0.06(0.13)$ & $0.05(0.08)$ & $0.08(0.16)$ \\
CEO duality & $0.64(0.48)$ & $0.5(0.51)$ & $0.78(0.42)$ & $0.56(0.5)$ & $0.54(0.5)$ & $0.57(0.5)$ \\
\hline
\end{tabular}

Regarding key explanatory variables, we may remark the following. For the first sub-period, 50 percent of the financial distressed firms are characterised by CEO duality versus 78 percent for their healthy counterparts. For the second sub-period, the percentage of capital held by the CEO is much smaller ( 8 percent) for financial distress firms than for the healthy group ( 5 percent).

Regarding control variables, it appears that the return on equity of firms having filed for a chapter 7 or 11 before 15 September 2008 was better than for their healthy counterparts. The situation is reversed for the second sub-period. Nevertheless, for the two periods, firms that have not met financial distress had a much better level of solvency.

\subsection{Logit Regressions}

In the next section, we briefly present results of the logit model; findings are discussed in greater detail. The results of the logit models are shown in Table 3. We build and test two models depending on the sub-period: before and after the filing date of the bank Lehman Brothers.

Table 3. Logit regressions before and after the filing date of Lehman Brothers on 15 September 2008

\begin{tabular}{|c|c|c|c|c|}
\hline \multirow[t]{2}{*}{ Variable } & \multicolumn{2}{|c|}{$\begin{array}{l}\text { Before } 15 \\
\text { September } 2008\end{array}$} & \multicolumn{2}{|c|}{$\begin{array}{l}\text { After } 15 \\
\text { September } 2008\end{array}$} \\
\hline & Beta & Std. Err. & Beta & Std. Err. \\
\hline Constant & $3.76 \dagger$ & 2.11 & $2.11^{*}$ & 0.9 \\
\hline \multicolumn{5}{|l|}{ Controls } \\
\hline ROE & -0.05 & 0.16 & -0.07 & 0.05 \\
\hline Solvency & $-3.87 * * *$ & 1.14 & $-2.93 * * *$ & 0.53 \\
\hline \multicolumn{5}{|l|}{ Direct Effects } \\
\hline Board size & $-0.25 \dagger$ & 0.14 & $-0.13 \dagger$ & 0.07 \\
\hline Board independence & 0.22 & 2.23 & -0.29 & 1.02 \\
\hline CEO ownership & 2.22 & 3.36 & $-3.31 *$ & 1.52 \\
\hline CEO duality & $-1.65^{*}$ & 0.66 & 0.11 & 0.31 \\
\hline Model Chi2 & \multicolumn{2}{|c|}{$31.02 * * *(6 \mathrm{df})$} & \multicolumn{2}{|c|}{$56.09 * * *(6 \mathrm{df})$} \\
\hline Sample Size & \multicolumn{2}{|l|}{$\mathrm{N}=72$} & \multicolumn{2}{|l|}{$\mathrm{N}=234$} \\
\hline Log Likelyhood & \multicolumn{2}{|l|}{-34.39} & \multicolumn{2}{|l|}{-134.15} \\
\hline
\end{tabular}

Note. $\dagger$ Partially significant at $\mathrm{P}<0.10 ; * * *, * * *$ Significant at $\mathrm{P}<0.05,0.01$, and 0.001 , respectively. 
Comparing the two models, we may notice similarities and differences.

First, higher solvency ratio has a negative impact on the probability of filing for a bankruptcy chapter; this observation is valid for the two models and so, for the two sub periods. Second, regarding direct effects, H1a and $\mathrm{H} 1 \mathrm{~b}$, which suggested that Board size had a negative impact on financial distress probability, is partially supported for the two models (Model 1: $\mathrm{b}=-0.25, \mathrm{p}<.10$; Model 2: $\mathrm{b}=-0.13, \mathrm{p}<.10$ ). Third, H2 ( $\mathrm{a}$ and $\mathrm{b}$ ) regarding the relationship between Board independence and financial distress is not supported in any of the two models. Fourth, the relationship between $C E O$ ownership and financial distress is only significant in model 2 (Model 2: $\mathrm{b}=-3.31, \mathrm{p}<.05$ ); H3b is supported. Moreover, the coefficient associated to this variable changes between model 1 and model 2. Fifth, H4 posited a positive relationship between CEO duality and the probability to file for a bankruptcy protection law; H4b is not supported. Contrarily, in model 1, the relationship between CEO duality and financial distress appears to be negative and significant at $5 \%$ threshold (Model $1: \mathrm{b}=-1.65, \mathrm{p}$ $<.05)$. Moreover, the coefficient associated to this variable changes between model 1 and model 2.

We discuss findings in greater detail in the next section.

\section{Discussion and Conclusions}

Given that corporate governance played a significant role in the perennity of firms following the subprime crisis, this study makes a contribution by examining the role of corporate governance among firms that resorted to bankruptcy protection between July 2007 and December 2009. Using a unique dataset from Bloomberg, we created a matched pair sample of US quoted firms that filed for reorganization/liquidation and those who did not. We then divided our sample into two parts according to their announcement date for bankruptcy filing: before and after September 15, 2008, the announcement date of the bankruptcy filing of the bank Lehman Brothers. The issue is to see if the same variables influence the bankruptcy before and after this event that we consider as a "hinge" between the mortgage and financial phases of the crisis. Using logit models, we then, for the two sub periods, examined the impact of governance characteristics on financial distress probability. We found that the size of the board was negatively related to financial distress occurrence for the two sub Periods. Nevertheless, our results highlight differences between the two sub periods; these concern the impact of ownership and CEO duality on financial distress probability. Regarding the impact of CEO ownership on financial distress probability, it appears to be positive and not significant for the first sub period and negative and significant for the second sub period. Regarding the impact of CEO duality on financial distress probability, it appears to be negative and significant for the first sub period and positive and not significant for the second sub period. So, it turns out that, during the first sub period, combining the functions of CEO and chairman of the board of directors is beneficial to the survival of the firm, whereas, during the second sub period, capital ownership by the CEO appears as an incentive to keep the firm on float. We can therefore assume that, during the mortgage phase of the subprime crisis, the unicity of command and the related reactivity allowed companies to avoid bankruptcy filing while during the financial phase, the incentive function related to the holding of capital (Jensen \& Meckling , 1976) has been discriminating in terms of resistance to the market shocks. We can therefore assume that, the combination of the functions of CEO and chairman has conferred companies a greater and decisive flexibility (Finet et al., 2005) during the mortgage episode of the crisis. During this sub period, decision-making structures have had to demonstrate increased reactivity, even if it means that the role of governance is, for a time, left out. It also appears that, during the financial part of the subprime crisis characterized by panic and uncertainty, doubts about the continuity of business operations, have motivated CEO's holding a "relatively" large share of capital of the company to act with a view to perennity.

There are limitations to this study. The results are contingent to our sample as well as the period considered. The comparison of our analysis with similar studies in other times and other geographic areas would release more robust conclusions about the impact of governance mechanisms on company perennity following a market shock.There are theoretical and managerial implications of this study. This research makes a contribution to the literature as corporate governance was partly successful in predicting financial distress probability. For managers and shareholders, this study finds that firms needed to pay close attention to the unicity of command during the mortgage part of the subprime crisis and to the alignment of the interests of the CEO with the ones of the shareholders during the financial part of the subprime crisis.

To conclude, this study makes a significant contribution to the literature and practice with regards to corporate governance and the subprime crisis. The results of this study would lead us to conclude that governance patterns do, in fact, contribute to the incidence of bankruptcy. The relationship between perennity and corporate governance remains relatively poorly investigated and many research questions still need to be explored by further empirical studies in order to improve the resistance of firms. 


\section{References}

Adams, M., Lin, C., \& Zou, H. (2011). Chief executive officer incentives, monitoring and corporate risk management: Evidence from insurance use. The Journal of Risk\& Insurance, 78(3), 551-582.

Altman, E. (1968). Financial ratios, discriminant analysis and the prediction of corporate bankruptcy. The Journal of Finance, 23(4), 589-609. http://dx.doi.org/10.1111/j.1540-6261.1968.tb00843.x

Attali, J. (2008). La crise, et après? Paris: Fayard.

Balsam, S., \& Upadhyay, A. (2009). Impact of board leadership on firm performance: does it matter who heads the board? Working Paper, Temple University, Philadelphia.

Beatty, R. P., \& Zajac, E. J. (1994). Managerial incentives, monitoring and risk bearing: A study of executive compensation, ownership \& board structure in initial public offerings. Administrative Science Quarterly, 39(2), 313-335. http://dx.doi.org/10.2307/2393238

Beaver, W. (1967). Financial ratios as predictors of failures. Journal of Accounting Research, Empirical Research in Accounting: Selected Studies, 71-111.

Bhagat, S., \& Bolton, B. (2008). Corporate governance and firm performance. Journal of Corporate Finance, 14(3), 257-273. http://dx.doi.org/10.1016/j.jcorpfin.2008.03.006

Boyd, B. (1995). CEO Duality and Firm Performance: A Contingency Model. Strategic Management Journal, 16(4), 301-312. http://dx.doi.org/10.1002/smj.4250160404

Chaganti, R., Mahajan, V., \& Sharma, S. (1985). Corporate board size, composition and corporate failures in retailing industry. Journal of Management Studies, 22(4), 400-417. http://dx.doi.org/10.1111/j.1467-6486.1985.tb00005.x

Cheng, S. (2008). Board size and the variability of corporate performance. Journal of Financial Economics, 87(1), 157-176. http://dx.doi.org/10.1016/j.jfineco.2006.10.006

Choi, J., Park, S., \& Yoo, S. (2005). Do outside directors enhance firm performance? Evidence from an emerging market. Working paper, Temple University, Philadelphia.

Conyon, M., Judge, W., \& Useem, M. (2011). Corporate governance and the 2008-2009 financial crisis. Corporate Governance: An International Review, 19(5), 399-404. http://dx.doi.org/10.1111/j.1467-8683.2011.00879.x

Cutting, B., \& Kouzmin, A. (2002). Evaluating corporate board cultures and decision making. Corporate Governance, 2(2), 27-45. http://dx.doi.org/10.1108/14720700210430324

Daily, C., \& Dalton, D. (1994). Corporate governance and the bankrupt firm: an empirical assessment. Strategic Management Journal, 15(8), 643-654. http://dx.doi.org/10.1002/smj.4250150806

Daily, C. (1996). Governance patterns in bankruptcy reorganizations. Strategic Management Journal, 17(5), 355-375. http://dx.doi.org/10.1002/(SICI)1097-0266(199605)17:5<355::AID-SMJ813>3.0.CO;2-S

Daily, C., Dalton, D., Ellestrand, A., \& Johnson, J. (1998). Meta-analytic reviews of board composition, leadership structure and financial performance. Strategic Management Journal, 19(3), 269-290. http://dx.doi.org/10.1002/(SICI)1097-0266(199803)19:3<269::AID-SMJ950>3.0.CO;2-K

Depret, M. H., Finet, A., Hamdouch, A., Labie, M., Missonier-Piera, F., \& Piot, C. (2005). Gouvernement d'entreprise: enjeux managériaux et financiers. Brussels: De Boeck.

Donoher, W. J. (2004). To file or not to file? Systemic incentives, corporate control, and the bankruptcy decision. Journal of Management, 30(2), 239-262. http://dx.doi.org/10.1016/j.jm.2003.02.003

Eisenberg, T., Sundgren, S., Wells, M. (1998). Larger board size and decreasing firm value in small firms. Journal of Financial Economics, 48(1), 35-54. http://dx.doi.org/10.1016/S0304-405X(98)00003-8

Gales, L. M., \& Kesner, I. F. (1994). An analysis of board of director size and composition in bankrupt organizations. Journal of Business Research, 30(3), 271-282. http://dx.doi.org/10.1016/0148-2963(94)90057-4

Hambrick, D., \& D'Aveni, R. (1992). Top team deterioration as part of the downward spiral of large corporate bankruptcies. Management Science, 38(10), 1445-1466. http://dx.doi.org/10.1287/mnsc.38.10.1445

Jensen, M. (1993). The modern industrial revolution, exit, and the failure of internal control systems. The Journal of Finance, 48(3), 831-880. http://dx.doi.org/10.1111/j.1540-6261.1993.tb04022.x 
Jensen, M., \& Meckling, W. (1976). Theory of the firm: managerial behavior, agency costs and ownership $\begin{array}{lllll}\text { structure. Journal of } & \text { Financial 305-360. }\end{array}$ http://dx.doi.org/10.1016/0304-405X(76)90026-X

Kiel, G., \& Nicholson, G. (2003). Board composition and corporate performance: how the Australian experience informs contrasting theories of corporate governance. Corporate Governance: An International Review, 11, 189-205. http://dx.doi.org/10.1111/1467-8683.00318

Lajili, K., \& Zeghal, D. (2010) Corporate Governance and Bankruptcy Filing Decisions. Journal of General Management, 35(4), 3-26.

Li, Y., \& Zhong, Z. (2013). Investing in chapter 11 stocks: Trading, value, and performance. Journal of Financial Markets, 16, 33-60. http://dx.doi.org/10.1016/j.finmar.2012.09.006

Lipton, M., \& Lorsch, J. W. (1992). A modest proposal for improved corporate governance. Business Law, 48(1), $59-77$.

Ohlson, J. (1980). Financial ratios and the probabilistic prediction of bankruptcy. Journal of Accounting Research, 18(1), 109-131. http://dx.doi.org/10.2307/2490395

Pi, L., \& Timme, S. (1993). Corporate Control and Bank Efficiency. Journal of Banking \& Finance, 20(2/3), 515-530. http://dx.doi.org/10.1016/0378-4266(93)90050-N

Platt, H. D., \& Platt, M. B. (1991). A note on the use of industry-relative ratios in bankruptcy prediction. Journal of Banking \& Finance, 15(6), 1183-1194. http://dx.doi.org/10.1016/0378-4266(91)90057-S

Platt, H., \& Platt, M. (2012). Corporate board attributes \& bankruptcy. Journal of Business Research, 65, 1139-1143. http://dx.doi.org/10.1016/j.jbusres.2011.08.003

Premachandra, I. M., Bhabra, G. S., \& Sueyoshi, T. (2009). DEA as a tool for bankruptcy assessment: a comparative study with logistic regression technique. European Journal of Operational Research, 193(2), 412-424. http://dx.doi.org/10.1016/j.ejor.2007.11.036

Rechner, P., \& Dalton, D. R. (1991). CEO Duality and Organizational Performance: A Longitudinal Analysis. Strategic Management Journal, 12(2), 155-161. http://dx.doi.org/10.1002/smj.4250120206

Rediker, K. J., \& Seth, A. (1995). Boards of directors and substitution effects of alternative governance mechanisms. Strategic Management Journal, 16(2), 85-99. http://dx.doi.org/10.1002/smj.4250160202

Refait, C. (2004). La prévision de la faillite fondée sur l'analyse financière de l'entreprise: un état des lieux. Economie \& Prévision, 162(1), 129-147.

Weisbach, M. (1988). Outside directors and CEO turnover. Journal of Financial Economics, 20, 431-460. http://dx.doi.org/10.1016/0304-405X(88)90053-0

Westphal, J. D., \& Zajac, E. J. (1995). Who shall govern? CEO/board power, demographic similarity, and new director selection. Administrative Science Quarterly, 40(1), 60-83. http://dx.doi.org/10.2307/2393700

Yermack, D. (1996). Higher market valuation of companies with a small board of directors. Journal of Financial Economics, 40, 185-211. http://dx.doi.org/10.1016/0304-405X(95)00844-5

\section{Note}

Note 1 . Solvency ratio $=$ Total Shareholders Equity/Total Assets.

\section{Copyrights}

Copyright for this article is retained by the author(s), with first publication rights granted to the journal.

This is an open-access article distributed under the terms and conditions of the Creative Commons Attribution license (http://creativecommons.org/licenses/by/3.0/). 